\title{
Individual Risk in an Investment-Based Social Security System
}

\section{Citation}

Feldstein, Martin, and Elena Ranguelova. 2001. Individual risk in an investment-based social security system. American economic review 91, no. 4: 1116-1125.

\section{Published Version}

http://papers.ssrn.com/sol3/papers.cfm?abstract_id $=256080$

\section{Permanent link}

http://nrs.harvard.edu/urn-3:HUL.InstRepos:2797440

\section{Terms of Use}

This article was downloaded from Harvard University's DASH repository, and is made available under the terms and conditions applicable to Other Posted Material, as set forth at http:// nrs.harvard.edu/urn-3:HUL.InstRepos:dash.current.terms-of-use\#LAA

\section{Share Your Story}

The Harvard community has made this article openly available.

Please share how this access benefits you. Submit a story.

Accessibility 


\title{
NBER WORKING PAPER SERIES
}

\section{INDIVIDUAL RISK IN AN INVESTMENT-BASED SOCIAL SECURITY SYSTEM}

\author{
Martin Feldstein \\ Elena Ranguelova \\ Working Paper 8074 \\ http://www.nber.org/papers/w8074 \\ NATIONAL BUREAU OF ECONOMIC RESEARCH \\ 1050 Massachusetts Avenue \\ Cambridge, MA 02138 \\ January 2001
}

Martin Feldstein is Professor of Economics, Harvard University, and President of the National Bureau of Economic Research. Elena Ranguelova is a doctoral candidate at Harvard University and a Research Assistant at the NBER. We are grateful for discussions about this subject with Andrew Abel, John Biggs, John Campbell, Jeff Liebman, Gilbert Metcalf, James Poterba, Antonio Rangel, Andrew Samwick, Kent Smetters, and Larry Summers and for comments from participants in various NBER meetings on Social Security. A more complete version of this paper is available on the NBER web site at www.nber.org/papers/w6839. A version based on earlier official actuarial estimates was circulated in 1998 as NBER Working Paper 6839. The views expressed herein are those of the authors and not necessarily those of the National Bureau of Economic Research.

(C) 2001 by Martin Feldstein and Elena Ranguelova. All rights reserved. Short sections of text, not to exceed two paragraphs, may be quoted without explicit permission provided that full credit, including $(\mathrm{C}$ notice, is given to the source. 
Individual Risk in an Investment-Based Social Security System

Martin Feldstein and Elena Ranguelova

NBER Working Paper No. 8074

January 2001

JEL No. H55

\begin{abstract}
This paper examines the risk aspects of an investment-based defined contribution Social Security plan. We focus on the risk after the plan is fully phased in. Individuals deposit a fraction of wages to a Personal Retirement Account (PRA), invest these funds in a 60:40 equity-debt mix, and in a similarly invested annuity at age 67 . The value of the assets follows a random walk with mean and variance of a 60:40 equity-debt portfolio over the period 1946-95, a mean log return of 5.5 percent (net of administrative costs of 0.4 percent) and a standard deviation of 12.5 percent. We study he stochastic distributions of this process by doing 10,000 simulations of the 80-year experience of the cohort that reached age 21 in 1998.

The resulting annuities are compared to the future defined benefits specified in current law (the "benchmark "benefits). With no uncertainty, a 5.5 percent log return would permit the benchmark benefits to be purchased with PRA deposits of 3.1 percent of payroll, only one-sixth of the pay-as-you-go tax needed for the benchmark benefits. Saving a higher share of wages provides a "cushion" that protects the individual from the risk of an unacceptably low level of benefits. For example, PRA deposits of 6 percent of wages reduces the probability that the benefits are less than the benchmark to 0.17 and the probability that they are less than 61 percent of the benchmark to 0.05 . PRA deposits of 9 percent of wages (half of the tax rate required in a pay-as-you-go system) would substantially reduce these risks.

This pure investment-based plan is an extreme case. The investment risk can be reduced further by using a mixed system that combines pay-as-you-go and investment-based components or that makes intergenerational transfers conditional on the performance of stock and bond prices.
\end{abstract}

Martin Feldstein

Harvard University

Cambridge, MA 02138

and NBER

feldstein@nber.org
Elena Ranguelova

Harvard University

Cambridge, MA 02138

and NBER

elena@nber.org 
The rapid aging of the population creates substantial financing problems for existing pay-as-you-go Social Security programs. Governments around the world are therefore considering shifting completely or partially to investment-based defined contribution plans in which employees contribute a fraction of their wages to individual accounts, invest the funds in a combination of stocks and bonds, and use the accumulated assets to finance a retirement annuity. Some governments have already made this shift. Such prefunded programs offer the prospect of financing future retirement benefits with substantially smaller sacrifices during working years than the taxes that would be required in traditional unfunded pay-as-you-go ("paygo") programs. They have the potential disadvantage, however, of exposing retirees to the uncertainty associated with the variable returns on stocks and bonds. Despite the importance of this issue, there has been no analysis of the magnitude of the risk to which retirees would be exposed in a system of individual defined contribution accounts.

The analysis in this paper takes the pay-as-you-go benefits promised in current law (essentially a continuation of current replacement rates) as the benchmark and shows that the risk that future retirees would receive less than this "benchmark" level of benefits in a pure defined contribution system would be relatively small at saving rates that are substantially less than the future paygo tax rate required to fund that benchmark level of benefits. This pure investment-based plan is an extreme case; the investment risk can be reduced by using a mixed system that combines pay-as-you-go and investment based components or that makes intergenerational transfers conditional on the performance of stock and bond prices (Feldstein and Ranguelova, 1998).

\section{Defined Contributions vs. Defined Benefits}

Samuelson (1958) established the well known result that individuals in a paygo system earn an implicit rate of return in a steady state equilibrium equal to the real rate of growth of the social security tax base, i.e., the sum of the growth rates of the labor force and real wages. The introduction of a new paygo plan provides an immediate windfall to those who are already retired or who will soon retire because they receive benefits with little or no previous 
contributions. Subsequent increases in benefits financed by higher tax rates provide similar windfalls to those who are then retired or soon to be retired. When program expansions can no longer provide such windfall gains, the implicit return of a paygo program eventually decreases to the Samuelsonian rate of aggregate wage growth. For the United States, this has averaged 2.5 percent over the past 30 years.

The return earned by any particular birth cohort will vary from the steady state rate in response to changes in the ratio of retirees to workers caused by changes in labor force participation, birth rates and death rates, and in the ratio of taxable wages to total compensation including fringe benefits. Caldwell et. al. (1998) estimate that current Social Security rules imply that the real rate of return on Social Security contributions will be 2.4 percent for the generation born right after World War II but only about 1 percent for those born in the 1970s and essentially zero for those born at the end of the 1990s. Because of the aging of the population, the Social Security actuaries (Board of Trustees, 1998) estimate that the current 12.4 percent tax rate will have to increase to more than 18 percent by the year 2035 to maintain the current benefit-wage replacement rates.

This combination of the low implied rate of return for current and future taxpayers and the prospect of a substantial increase in future Social Security tax rates has stimulated interest in investment-based alternatives to the current pay-as-you-go system. The fundamental economic difference between the two approaches is that the investment based system involves an initial reduction of national consumption and a concurrent increase in the national capital stock. The rate of return in an investment-based plan is therefore the marginal product of capital, a number substantially greater than the rate of growth of aggregate wages. Note that the relative advantage of an investment based plan depends on the marginal product of capital relative to the growth rate of wages and not on the return on equity investments relative to the return on government bonds, as some have suggested.

A simplified calculation indicates the large effect of this difference in rates of return on the cost of funding retirement benefits. Assume an overlapping generations framework in 
which there are $\mathrm{T}$ years between generations. In the paygo system, individuals receive benefits $\mathrm{T}$ years after they pay tax; in the investment-based system, individuals spend their accumulated assets $\mathrm{T}$ years after they make the savings deposit. If the implicit rate of return in a paygo system is denoted $\gamma=n+g$ here $n$ is the growth rate of the labor force and $g$ is the rate of growth of average wages, the Samuelson (1958) analysis implies that each dollar of retirement income at time $\mathrm{T}$ requires a tax payment of $\exp (-\gamma T)$ dollars at the earlier contribution date. Similarly, if $\rho$ is the marginal product of capital, each dollar of retirement income at $\mathrm{T}$ requires a contribution to the personal retirement account $(\mathrm{PRA})$ of $\exp (-\rho T)$ at the contribution date. The ratio of the PRA contribution to the paygo tax payment to finance the same benefit $\mathrm{T}$ years later is $\exp (\gamma-\rho) T$. With $\gamma=0.025, \rho=0.085$ and $\mathrm{T}=30$ years, $\exp (\gamma-\rho) T=0.165$, i.e., each dollar of tax payment required in a paygo system can be replaced by just 16.5 cents in a funded program with an 8.5 percent rate of return. The 18 percent future payroll tax rate projected by the Social Security Administration could in principle be replaced by a funded program with mandatory contributions equal to 3.0 percent of earnings.

This comparison of the potential long-run gains from switching to an investment-based system $^{1}$ ignores not only the risk issues that are the subject of this paper but also questions about (1) how the paygo benefits are financed during the transition to an investment based system, (2) the administrative costs of an investment based plan, and (3) the distributional consequences of substituting an investment based plan for the existing paygo system. These issues are discussed extensively elsewhere (Diamond (1997), Feldstein (1996), Feldstein and Samwick (1997, 1998a,1998b), Kotlikoff (1998), Shoven (1999), and Feldstein and Liebman (1999)) and will not be considered here.

\footnotetext{
${ }^{1}$ There is a present value gain at the time of the switch if corporate and personal capital income taxes cause the net-of-tax rate at which individuals discount future consumption to be less than the marginal product of capital. There is no present value gain if this tax wedge is ignored and the rate of discount is assumed equal to the marginal product of capital; see Murphy and Welch (1998) and Geanakoplos, Mitchell and Zeldes (1998).
} 


\section{An Investment-Based Defined Contribution Plan with Variable Annuity Benefits}

This section describes the system of Personal Retirement Accounts in which a representative individual accumulates assets that are converted to a variable rate annuity at the time of retirement. Individuals who die before retirement remain in the annuity pool (although alternative bequest rules are possible, as explained in Feldstein and Ranguelova (1999).) The representative individual enters the labor force at age 21 and retires at age 67 (if he or she is still alive). For the sake of concreteness, we use the economic and demographic projections of the Social Security Administration (Board of Trustees, 1998) for the cohort reaching age 21 in 1998. We assume that the representative individual has his birth cohort's average earnings at each age and experiences the cohort's age-specific mortality rates.

In the defined benefit plan specified in the current Social Security law, an individual with such average earnings experience would receive a benefit at age 67 for himself equal to 40 percent of his immediate preretirement wage. The full defined benefit benchmark in our simulations is a multiple of this amount that reflects benefits for a spouse or other dependants as well as disability benefits. Instead of modeling such additional benefits explicitly, we use a multiple of the individual benefit such that the implied aggregate Social Security benefits in each year beginning in 2030 is equal to the aggregate benefit projected by the Social Security Administration. The aggregate benefits projected in this way together with the aggregate wage income projected by the Social Security Administration (Board of Trustees, 1998) imply that the paygo tax rate required to pay benefits will be 18.4 percent when the cohort that we study retires (in contrast to the current tax rate of 12.4 percent). These assumptions about future defined benefits do not affect the projected behavior of the

defined contribution annuities but provide a benchmark for comparing the relative costs of defined benefit and defined contribution programs. 
With a defined contribution plan, the individual contributes a fixed percentage of wages in each year to a Personal Retirement Account (PRA); we will examine the implications of different saving rates from 4 percent to 9 percent (i.e., up to half of the longrun paygo tax rate of 18.4 percent). The individual invests these savings in a portfolio that is continually rebalanced to maintain 60 percent equities and 40 percent debt, a ratio that corresponds approximately to the debt-equity ratio of U.S. corporations so that the portfolio rate of return corresponds to the return on corporate capital without considerations of the relative yields on debt and equity. At retirement, these accumulated assets are used to finance a variable annuity in which annual benefits vary with portfolio performance in a way described below.

We use the S\&P500 index and a Salomon Brothers corporate bond index as proxies for the stock and bond investments. Both indices are assumed to follow a geometric random walk with drift. his implies that the log returns for each type of asset are serially independent and identically distributed with given mean and variance. Thus if $p_{e}(s)$ and $p_{b}(s)$ are the $\log$ levels of the equity and bond indices at time $\mathrm{s}$, we assume $\mathrm{p}_{\mathrm{e}}(\mathrm{s})=\mathrm{p}_{\mathrm{e}}(\mathrm{s}-1)+\mu_{\mathrm{e}}+\mathrm{u}_{\mathrm{e}}(\mathrm{s})$ and $\mathrm{p}_{\mathrm{b}}(\mathrm{s})=\mathrm{p}_{\mathrm{b}}(\mathrm{s}-1)+\mu_{\mathrm{b}}+\mathrm{u}_{\mathrm{b}}(\mathrm{s})$ where $\mathrm{u}_{\mathrm{e}} \sim$ iid $\mathrm{N}\left(0, \sigma_{\mathrm{e}}^{2}\right)$ and $\mathrm{u}_{\mathrm{b}} \sim$ iid $\mathrm{N}\left(0, \sigma_{\mathrm{b}}^{2}\right)$. The covariance between the stock and bond returns is $\sigma_{\mathrm{e} \mathrm{b}}$.

With a continuously compounded 60:40 equity-debt portfolio, the log level of the overall portfolio would, if there were no additions or payments, satisfy p (s) $=\mathrm{p}(\mathrm{s}-1)+\mu+$ $\mathrm{u}(\mathrm{s})$ with $\mathrm{u} \sim$ iid $\mathrm{N}\left(0, \sigma^{2}\right)$. (In practice, the value of the PRA portfolio is also increased by the annual savings of a fraction of the individual's wage plus the distributed share of the PRA balances of all those members of the age cohort who die during the previous year; the explicit evolution is shown below.) To derive the values of $\mu$ and $\sigma^{2}$ we use the lognormal property of the returns. More specifically, if $\mu^{*}$, is the mean return on asset $\mathrm{i}$ in level form, the mean return on the 60:40 portfolio is the weighted average $\mu^{*}=0.6 \mu_{\mathrm{e}}+0.4 \mu_{\mathrm{b}}{ }^{*}$. Because we assume the log returns to be normally distributed, $\mu_{\mathrm{i}}=\mu_{\mathrm{i}}+0.5 \sigma_{\mathrm{i}}^{2}$. This implies that $\mu+0.5 \sigma^{2}=0.6\left(\mu_{\mathrm{e}}+0.5 \sigma_{\mathrm{e}}^{2}\right)+0.4\left(\mu_{\mathrm{b}}+0.5 \sigma_{\mathrm{b}}^{2}\right)$ where 
$\sigma^{2}=0.36 \sigma_{\mathrm{e}}^{2}+0.16 \sigma_{\mathrm{b}}^{2}+0.48 \sigma_{\mathrm{eb}}$. From these two equations and the measured mean and variance of the log returns on stocks and bonds we can derive the log return on the portfolio and the variance of that return.

The CRSP data for the postwar period from 1946 through 1995 imply that for stocks and bonds the mean real log rates of return were 7.0 percent and 3.3 percent. ${ }^{2}$ The corresponding standard deviations are 16.6 percent for stocks and 10.4 percent for bonds. The covariance of the stock and bond returns is $\sigma_{\mathrm{eb}}=0.0081$. Taken together, these parameters imply a logarithmic rate of return on the 60:40 portfolio of 5.9 percent with a standard deviation of 12.5 percent. We reduce the mean return from 5.9 percent to 5.5 percent to reflect potential administrative costs, more than the 0.2 percent charged now by major index funds or the 37 basis point fee for the combined saving and variable annuity product recently introduced by TIAA-CREF.

In the analysis that follows, we recognize that the adjusted mean real log return of 5.5 percent for the portfolio during the period from 1946 through 1995 is only an estimate of the relevant mean for future years. Our stochastic simulation therefore uses a two step procedure to simulate the uncertain future annual returns. For each of 10,000 simulations, we begin by generating a mean real log return on the portfolio from a normal distribution with a mean of 0.055 and a standard deviation of 0.0175 which is equal to the standard error of the

\footnotetext{
${ }^{2}$ The mean portfolio return is essentially unchanged if we use a longer time period from 1926 to 1997 . The annual bond rates of return are based on the Salomon Brothers AAA bond returns adjusted to a more typical corporate bond yield by adding two percentage points. Although there are no comparable data on the annual holding period return of lower grade bonds, the variance of such bond yields would presumably be higher and the correlation with equity yields would also differ. We do not attempt to take these into account. The effect of ignoring this would almost certainly be small relative to the understatement of the mean return that results from ignoring the additional corporate tax revenue that the government receives because of the increased capital stock. Estimates by Poterba (1997) imply that the corporate taxes on capital and capital income collected by federal, state and local governments is equivalent to 3.4 percent of the incremental capital. The federal corporate tax alone is equivalent to an additional 2.2 percent per cent return. Although a specific mechanism for crediting these taxes is not considered in this paper, they should be recognized as part of the return of an investment based system. See Feldstein and Ranguelova (1998) for a more complete analysis of this corporate tax revenue.
} 
estimated mean based on the number of years in the sample. We then use this estimated realization of the mean and the standard deviation of 0.125 to generate a 71 year sequence of portfolio returns from the year 2000 to 2070 . We repeat this 10,000 times.

Although the equation for $\mathrm{p}(\mathrm{s})$ describes the way that the logarithmic value of the PRA account would evolve during the accumulation years if there were no external additions, in practice the actual individual PRA account is also augmented by the fraction ..of the individual's wage and by the distributed share of the PRA balances of those members of the cohort who die during the year. We simulate this evolution at the level of the birth cohort (rather than of the individual) by: $\mathrm{M}(\mathrm{s})=[1+\mathrm{R}(\mathrm{s}-1)] \mathrm{M}(\mathrm{s}-1)+a \mathrm{w}(\mathrm{s}) \mathrm{N}(\mathrm{s})$ where $\mathrm{M}(\mathrm{s})$ is the aggregate PRA balance for the cohort as a whole, $\mathrm{R}(\mathrm{s})$ is the rate of return in period $\mathrm{s}$, $\mathrm{N}(\mathrm{s})$ is the number of living members of the cohort, w(s) is average wage and $a$ is the share of wages that is saved and contributed to the PRA accounts. Since this equation is in level rather than logarithmic form, the value of $1+\mathrm{R}(\mathrm{s})=\exp [\mathrm{r}(\mathrm{s})]$ where $\mathrm{r}(\mathrm{s})$ is the logarithmic rate of return in period $\mathrm{s}$ implied by $\mathrm{r}(\mathrm{s})=\mathrm{p}(\mathrm{s})-\mathrm{p}(\mathrm{s}-1)=\mu+\mathrm{u}(\mathrm{s})$. Note that $\mathrm{E}[\mathrm{r}(\mathrm{s})]=$ 0.055 and the standard deviation of $\mathrm{r}(\mathrm{s})=0.125$ imply that $\mathrm{E}[1+\mathrm{R}(\mathrm{s})]=\mathrm{E}\left[\mathrm{e}^{\mathrm{r}(\mathrm{s})}\right]=\mathrm{e}^{\mathrm{E}[\mathrm{r}(\mathrm{s})]+0.5 \sigma^{2}}=$ 1.065 .

\subsection{The Variable Annuity}

We assume that this same stock-bond portfolio is used to finance the variable annuity during retirement. A variable annuity adjusts the annual benefit according to the changes in the value of the accumulation account. More specifically, the initial annuity benefit that is paid at age 67 (on an annuity purchased at age 66) reflects the PRA assets at the beginning of the individual's $66^{\text {th }}$ year, the expected mortality rates at all future ages, and the assumption that the future return will be equal to the expected log return of 5.5 percent. No adjustment in the rate of return is needed to compensate for the uncertainty because the individual retirees bear the risk of fluctuations in the rate of return.

One year later, the size of the variable annuity payment is increased or decreased from 
the initial value in proportion to the change in the market value of the PRA assets relative to the market value that would have prevailed if the expected 5.5 percent log return had actually occurred. A similar revision of the annual annuity payment occurs in each subsequent year.

To derive the explicit value of the variable annuity, consider the individuals in a particular birth cohort. Let the time index coincide with the age of the cohort so that $\mathrm{N}_{\mathrm{t}}$ is the number of individuals alive at age t. Let $\mathrm{A}_{66}$ be the be the value of the PRA assets at the beginning of the $66^{\text {th }}$ year and let $\mathrm{R}$ be the expected annual real rate of return on the portfolio of assets used to finance the retirement annuity. The first annuity benefit is paid at the beginning of the individual's $67^{\text {th }}$ year and annually thereafter. The cost at age 66 of a fixed real annuity of $\$ 1$ for life (i.e., an annuity that starts with $\$ 1$ and grows in proportion to the level of consumer prices) is the actuarial present value (APV) of that dollar with the discount rate equal to the expected real rate of return on the investment portfolio:

$$
A P V=\sum_{t=67}^{100} \frac{N_{t}}{N_{66}}(1+R)^{-(t-66)}
$$

where we assume that all individuals alive at age 99 die at the end of the $100^{\text {th }}$ year.

Since the PRA account has assets equal to $\mathrm{A}_{66}$ when the annuity is established, the annual annuity payment that the individual would receive in the $67^{\text {th }}$ year is $a_{67}=\frac{A_{66}}{A P V}$

if the expected return of $\mathrm{R}$ is actually realized in the $66^{\text {th }}$ year. More generally, if the expected return $\mathrm{R}$ is realized in every future year, the individual would continue to receive that same annuity payment and the accumulated assets at age 66 of all members of that birth cohort would be exhausted when the last member of the cohort dies at age 100 .

In practice, of course, the actual rate of return varies from year to year. The annuity payments are adjusted in proportion to the annual changes in the asset value in such a way that the birth cohort's accumulated fund is still exhausted over the 34 year retirement period. If $R_{t}$ is the actual rate of increase of the asset value during year $t$, the asset value at the beginning of the cohort's $67^{\text {th }}$ year is $A_{67}=A\left(1+R_{66}\right)$. The annuity paid in that year is 
therefore $\mathrm{a}_{67}=\frac{A_{66}}{A P V} \times \frac{1+R_{66}}{1+R}$. Similarly the annuity at age 68 reflects the changes in the market value of the assets during the $66^{\text {th }}$ and $67^{\text {th }}$ years:

$$
a_{67}=a_{66} \frac{1+R_{67}}{1+R}=\frac{A_{66}}{A P V} \times \frac{1+R_{67}}{1+R} \times \frac{1+R_{66}}{1+R} .
$$

The last payment to those who are 100 years old is $a_{100}=a_{99} \frac{1+R_{99}}{1+R}$. Note that if the rate of return in each period is equal to the expected rate of return the annuity remains constant at $a_{67}$.

\section{Individual Risk in a Defined Contribution Plan}

In this section we assess the risk that an individual will receive an unacceptably low retirement annuity in an investment-based defined contribution plan. More specifically, we estimate the distribution of annuity values associated with different PRA saving rates and relate those annuity levels to the benefits currently promised in the Social Security defined benefit paygo system. We refer to this level of future benefits promised in current law as the "benchmark" Social Security benefits, mindful of the fact that these benefits could only be provided in a paygo system by increasing taxes substantially and that there are many proposals to reduce actual future benefits. We use these calculations to assess the extent to which individuals can reduce the risk of receiving a low annuity by using a higher saving rate while still saving less than the amount that would be paid in taxes in a pure paygo system.

Before examining the implications of the uncertain portfolio returns, it is useful to note the saving rate that would be required to fund the future benchmark Social Security benefits if the representative individual received the mean log return of 5.5 percent during both the preretirement accumulation and the retirement annuity. The annuity is calibrated to correspond not only to the benefit of the individual retiree but also to include dependents' benefits and disability benefits in a way that matches the projected aggregate OASDI benefits (as described above). The payroll tax required to finance these benefits in a pure paygo program is projected to rise to 18.4 percent of earnings as the ratio of retirees to 
employees increases. In contrast, a 3.1 percent saving rate (as a percentage of the same total earnings) would provide the same benefits in a defined contribution plan with a 5.5 percent rate of return.

The variability of portfolio returns implies that saving this amount will produce a retirement annuity that may either exceed or fall short of the benchmark Social Security benefit. To assess the probability distribution of the annuities, we generate the 10,000 simulations described above of the 80 year sequence of portfolio returns corresponding to the years when the members of the birth cohort are aged 21 through 100. For each of these 10,000 time series, we generate the path of PRA assets and variable annuity payments corresponding to different saving rates from 4 percent of earnings to 9 percent of earnings.

With a saving rate of 4 percent of earnings the median annuity at age 67 (in the 10,000 simulations) is 41 percent more than the benchmark Social Security benefit; see column 1of Table 1. In 66 percent of the simulations the annuity at age $67\left(a_{67}\right)$ exceeds the benchmark Social Security benefit. But in the worst 10 percent of the simulations, the annuity is less than 52 percent of the benchmark Social Security benefit. Because of this risk of a low annuity, it would be prudent for individuals to save a higher fraction of earnings.

Before looking at the implication of increasing the saving rate, consider the corresponding annuity distributions for older retirees. The median ratio of the defined contribution annuity to the benchmark Social Security benefit declines gradually as the cohort ages (1.41 at age 67, 1.30 at age 77, and 1.22 at age 87 ) but remains substantially greater than 100 percent of the benchmark. Similarly, the fraction of times that the annuity would exceed the benchmark Social Security benefit decreases monotonically with age: from 66 percent at age 67 to 56 percent at age 87. The annuity level at the tenth percentile also becomes lower as the cohort ages, declining from 52 percent of the benchmark Social Security benefit at age 67 to 37 percent of benefits at age 77, 27 percent at age 87. It is clear from these figures that it would be desirable to consider a higher saving rate during working years.

Increasing the saving rate to 6 percent achieves a very substantial reduction in the 
risk of low benefits as well as an increase in the size of the annuity associated with average portfolio performance. The median annuity at age 67 is now 2.12 times the benchmark Social Security benefit; see column 2 of Table 1 . Since the benchmark benefit for an individual retiree is about 40 percent of preretirement earnings, this corresponds to a replacement rate of 85 percent of preretirement earnings.

The six percent saving rate reduces the probability that the annuity at age 67 is less than the benchmark Social Security benefit to 17 percent. There is only a 5 percent chance that the age 67 annuity is less than 61 percent of the benchmark Social Security benefit.

Increasing the saving rate to 9 percent (still less than half of the projected pay-as-yougo tax rate) raises the distribution of benefits substantially. There is less than a 10 percent chance that the benefit is less than 1.1 times the benchmark level and less than a 5 percent chance that it is less than 92 percent of the benchmark benefit.

This favorable performance continues at older ages. The median annuity is nearly twice the benchmark Social Security benefit at age 77, and 1.83 times the benchmark at age 87. The probability of receiving an annuity that is less than the benchmark benefit remains low, rising from 17 percent at age 67 to less than 31 percent at 87 .

In considering these favorable distributions, it is worth emphasizing that the paygo tax required to finance the benchmark Social Security benefits that are used as the standard of comparison will rise to more than 18 percent during the next 40 years. Individuals could instead achieve much higher expected benefits and face only very little risk of lower benefits while saving substantially less than the long-run paygo tax rate.

\subsection{A CRRA Expected Utility Evaluation}

Although we believe that displaying the probability distributions of possible outcomes, as we do in Table 1, is the best way to indicate the risks and rewards of the alternative investment-based options, we now present explicit summary calculations based on expected values of constant relative risk aversion (CRRA) utility functions. To evaluate the PRA 
options presented in Table 1, we consider a representative individual with expected utility function

$$
E U=\mathrm{E}\left[\sum_{t=21}^{100} p_{t} \beta^{t-21} u\left(C_{t}\right)\right]
$$

where Eis the expectation operator, $u\left(C_{t}\right)=\frac{C_{t}^{1-\gamma}-1}{1-\gamma}$ with $\gamma$ here being the coefficient of relative risk aversion, $p_{t}$ is the probability of surviving to age $\mathrm{t}$ from age $21, \beta$ is the time discount factor at which utility is discounted, and $\gamma$ is the coefficient of relative risk aversion. We do the analysis with a time discount factor of 0.98 ; alternative calculations with a greater time discount $(\beta=0.96)$ and with no time discount factor $(\beta=1)$ have very little effect on the results that we report below. We recognize the restrictive nature of this specification. The function is additively separable and the relative risk aversion in each period, $-\frac{u^{\prime \prime} c}{u^{\prime}}=\gamma$, is a constant and is independent of age. Despite these limitations, these calculations may be useful to some readers as a supplement to the direct information of Table 1.

We evaluate this function for a representative agent who is age 21 in 1998. The individual earns the age specific wage for this cohort projected by the Social Security actuaries and pays a proportional income tax equal to 20 percent of that wage. With a 6 percent rate of PRA saving, the net income during the working years from age 21 to age 66 is 74 percent of the gross wage. (Although we are looking at officially projected wages beginning in 19981, to avoid the complexities of modeling the transition we compare a fully phased in PRA system with the paygo system that would exist in the more distant future.) The individual is assumed to do no other saving, making the consumption in each preretirement year the same 74 percent of pretax wages, a feature that makes the individual's utility more sensitive to fluctuations in the return to PRA saving. During retirement the individual's consumption is the variable annuity that is generated by the PRA savings, as described in section 2.1 above. Similar simulations are done also for PRA plans with saving rates of 4 
percent and 9 percent. We contrast each of these to a paygo system in which the tax rate is 18 percent, making the net consumption during the preretirement years equal to 62 percent of preretirement income. This paygo system is assumed to provide the benchmark level of benefits prescribed in current law during each retirement year with no uncertainty.

The coefficient of relative risk aversion is the key parameter in this expected utility evaluation. The values of inferred in the finance literature from the difference between the yields on stocks and on "risk free" treasury bills are implausibly high, giving rise to the label "equity premium puzzle." Instead of using these implausibly high values, we use the following mental experiment to help decide on appropriate CRRA values.

The representative individual in our example will reach age 67 in the year 2044 and will be retired during the decades that follow. The level of retirement consumption that the PRA will provide at that time might be conservatively approximated to be $\$ 40,000$ in today's prices; the precise level does not matter for our example. Consider two equally probable states of nature. In the good state the retiree has income and consumption of $\$ 40,000$. In the bad state, it is only $\$ 20,000$. In the mental experiment, we give the individual the opportunity to increase consumption in the bad state by one dollar by agreeing to reduce consumption if the good state occurs. We can infer the individual's CRRA $\gamma$ coefficient by observing how much the individual would be willing to give up in the good state to increase consumption in the bad state by one dollar.

Any risk averse individual $(\gamma>0)$ would be willing to give up more than a dollar in the good state for a dollar in the bad state. If the individual would give up two dollars in the good state, but no more, to increase consumption in the bad state by one dollar, we infer that $u^{\prime}=(20,000)=2 u^{\prime}=(40,000)$. Since the CRRA form noted above implies $u^{\prime}(c)=C^{1-\gamma}$, the

\footnotetext{
${ }^{3}$ See for example Mehra and Prescott (1985) and Kocherlakota (1996). The difference between the equity yield and the yield on Treasury bills has of course declined in recent years, implying a lower measure of risk aversion. If the "riskless" security is taken to be an asset with no credit risk and with a guaranteed long-term real return, the comparison should be the recently created Treasury Inflation Protected Securities. These TIPS now have a yield of about 4 percent, not that different from the earnings-price ratio on equities.
} 
condition that $u^{\prime}=(20,000)=2 u^{\prime}=(40,000)$ implies that $2 \gamma=2$ or $\gamma=1$.

Similarly, we can infer that if the representative individual is willing to give up four dollars of consumption in the good state (when consumption would otherwise be $\$ 40,000$ ) to have an additional dollar of consumption in the bad state when consumption would otherwise be $\$ 20,000$, the coefficient of CRRA becomes $\gamma=2$. And a representative individual who would give up eight dollars in the good state for one extra dollar in the bad state has a CRRA value of $\gamma=3$.

Readers can decide how much is reasonable to assume that someone would give up when income is $\$ 40,000$ for a dollar when the income would otherwise be $\$ 20,000$. Without choosing a specific value, we believe that the plausible sacrifice amount would be less than eight dollars and probably less than four dollars, i.e., $\gamma<3$ and probably $\gamma<2 .{ }^{4}$

We drew 10,000 independent histories of the 80-year sequence (from age 21 in 1998 to age 100 in 2077) of returns on the PRA savings of the representative individual and calculated the expected utility value associate with each value of $\gamma$. Our calculations show that the PRA with a 6 percent mandatory saving rate is preferable to the paygo for the relative risk aversion coefficient up to $\gamma=3.4$. With a 4 percent saving rate the critical value of $\gamma$ is 2.95 while with a 9 percent saving rate the PRA system is preferred to paygo for all values of $\gamma$ less than 3.85 .

The comparison of the expected lifetime utilities of the PRA and the paygo systems reflects time preference as well as risk preference. During the individuals' working years, the paygo requires an 18 percent tax while the PRA only involves a saving rate of between 4 percent and 9 percent. Differences in time preference (in our analysis) therefore influence the relative desirability of the two options. To abstract from this and focus just on the difference

\footnotetext{
${ }^{4}$ These values of gamma do not imply enough risk aversion to explain why some households do not invest in equities. However, many individuals may not because the cost of learning how to invest in equities exceeds the extra return on their very small amount of financial assets. Half of U.S. households approach retirement age with less than $\$ 12,000$ in financial assets. With $\$ 10,000$ of investable funds, the extra real return from investing in equities might be about $\$ 400$ a year.
} 
between the presumed-certain paygo benefit and the stochastic PRA annuity, we apply the expected utility calculation just to the incomes in the retirement years. In other words, we disregard the PRA system's advantage of requiring much lower contributions during working years than the 18 percent paygo tax. With a saving rate of 6 percent, the median PRA annuity is substantially greater than the benchmark benefit; table 1 shows that the median PRA annuity at age 67 is 2.12 times the benchmark benefit. Although there is a 17 percent chance that the PRA annuity will fall below the benchmark benefit at age 67 (and a greater chance at higher ages), the explicit utility evaluation starting at age 67 shows that the stochastic PRA annuity is preferred to the "certain" paygo benefit for all CRRA coefficients up to 2.4. With a four percent saving rate this critical value of becomes 1.6 while with a saving rate of 9 percent the PRA option is preferred for all values of up to 3.1. In short, for plausible CRRA risk aversion parameters, the preference for the PRA option does not depend on the lower contribution during the working years.

\section{Concluding Remarks}

This paper examines the risk aspects of an investment-based defined contribution Social Security plan. We focus on the risks after the plan is fully phased in so that all employees and retirees are participants in the plan. To be concrete, we base our calculations on the detailed projections of economic and demographic variables by the Social Security Administration and the Census Bureau for the 80 year period beginning in 1998. We assume that the new defined contribution program begins with the birth cohort that is 21 in 1998 .

In this plan, individuals are required to deposit a specified fraction of wages to a Personal Retirement Account, invest these funds in a 60:40 equity-debt mix, and in a similarly invested variable annuity at age 67 . The value of the assets in the Personal Retirement Accounts follows a random walk with the mean and variance of a 60:40 equitydebt portfolio over the period from 1946 to 1995, a mean log return of 5.5 percent (net of administrative costs of 0.4 percent) and a standard deviation of 12.5 percent. We study 
stochastic distributions of this process by doing 10,000 simulations of the 80 year experience from 1998 to 2077.

The resulting annuities are compared to the future defined benefits promised in the current Social Security law, a level that we refer to as the "benchmark" Social Security benefits. The Social Security actuaries calculate that the aging of the population and increased longevity imply that the future Social Security payroll tax required to finance the benchmark benefits on a pay-as-you-go basis would be greater than 18 percent.

If the 5.5 percent mean log rate of return were known with certainty, individuals could purchase the benchmark level of benefits by saving 3.1 percent of earnings, just one-sixth of the required tax in the pay-as-you-go plan. But the uncertain nature of the rate of return implies that saving 3.1 percent of wages could produce an annuity that is unacceptably less than the benchmark benefits.

Saving a higher share of wages provides a "cushion" that protects the individual from the risk of an unacceptably low level of benefits. For example, an individual who saves 6 percent of his earnings during his working years from 21 to 66 (with a 5.5 percent mean log return) has a 50 percent chance of receiving an annuity at age 67 that is at least 2.1 times the benchmark level of Social Security benefits (and therefore about 70 percent of preretirement pretax wages) and only a 17 percent chance that that annuity is less than the benchmark Social Security benefit. In 95 percent of the investment experience the annuity exceeds 61 percent of the benchmark benefit. A pure defined contribution plan with a 6 percent saving rate invested in a 60:40 equity-debt Personal Retirement Account can cut the individual's cost of providing a retirement annuity to one-third of the projected 18 percent pay-as-you go tax while leaving the retiree exposed to relatively little risk that the resulting annuity will be less than the benchmark level of Social Security benefits projected in current law.

Cambridge, MA

July 1998; Revised: July 2000 


\section{References}

Board of Trustees (1998), The 1998 Annual Report of the Social Security Trustees, Washington, DC.

Caldwell, Steven, et al., "Social Security's Treatment of Postwar America," in Tax Policy and the Economy (1998), James Poterba (ed.) Cambridge, MA: MIT Press, 1998.

Diamond, Peter, "Macroeconomic Aspects of Social Security Reform," Brookings Papers on Economic Activity 2, 1997, Brookings Institution, Washington, DC, pp 1 - 88.

Feldstein, Martin, "The Missing Piece in Policy Analysis: Social Security Reform," The Richard T. Ely Lecture, in American Economic Review, 86(2), May 1996, pp 1 - 4.

Feldstein, Martin and J. Liebman, "Distributional Effects of an Investment-Based Social Security System," NBER Working Paper, 1999

Feldstein, Martin and E. Ranguelova, "Individual Risk and Intergenerational Risk Sharing in an Investment Based Social Security System," NBER Working Paper 6839, December 1998

Feldstein, Martin and E. Ranguelova, "The Economics of Bequests in pensions and Social Security," NBER Working Paper No. 7065, April 1999.

Feldstein, Martin and A. Samwick, "The Economics of Prefunding Social Security and Medicare Benefits, NBER Macroeconomics Annual 1997, Cambridge, MA: MIT Press, pp $115-147$.

Feldstein, Martin and A. Samwick, "The Transition Path in Privatizing Social Security, in M. Feldstein (ed.) Privatizing Social Security, (Chicago: University of Chicago Press), 1998a, pp $215-60$.

Feldstein, Martin and A. Samwick, "Potential Effects of Two Percent Personal Retirement Accounts," Tax Notes, 79(5), May 4, 1998b, pp 615 - 20.

Geanakoplos, John, O.S. Mitchell and S.P. Zeldes, "Would a Privatized Social Security System Really Pay a Higher Rate of Return?" Pension Research Council Working 
Paper No. 98-6, June 1998, University of Pennsylvania, Philadelphia, PA.

Kocherlakota, Narayana, "The Equity Premium Puzzle: It's Still a Puzzle," Journal of Economic Literature, 34, 1996, pp 42 - 71

Kotlikoff, Laurence, "Simulating the Privatization of Social Security in General Equilibrium," in M. Feldstein (ed.), Privatizing Social Security, (Chicago: University of Chicago Press, 1998).

Mehra, Rajnish and E. Prescott, "The Equity Premium Puzzle," Journal of Monetary Economics, volume 15, 1985, pp 145 - 161.

Murphy, Kevin and F. Welch, "Perspectives on the Social Security Crisis and Proposed Solutions," The American Economic Review, Vol. 88, No. 2, May 1998, pp 142-50.

Poterba, James, "The Rate of Return to Corporate Capital and Factor Shares," NBER Working Paper No. 6263, 1997.

Samuelson, Paul, "An Exact Consumption Loan Model of Interest With or Without the Social Contrivance of Money, Journal of Political Economy, December 1958.

Shoven, John, Administrative Aspects of Social Security Reform, 1999 (forthcoming) 
Table 1

\section{Distribution of the Variable Annuity Payments as a Fraction of Benchmark Social Security Benefits Based on Mean Log Return of 5.5 Percent}

\begin{tabular}{|c|c|c|c|c|c|c|c|c|c|}
\hline \multirow{3}{*}{$\begin{array}{l}\text { Cumulative } \\
\text { Probability }\end{array}$} & \multicolumn{3}{|c|}{ Age 67} & \multicolumn{3}{|c|}{ Age 77} & \multicolumn{3}{|c|}{ Age 87} \\
\hline & \multicolumn{3}{|c|}{ Saving Rate } & \multicolumn{3}{|c|}{ Saving Rate } & \multicolumn{3}{|c|}{ Saving Rate } \\
\hline & 0.04 & 0.06 & 0.09 & 0.04 & 0.06 & 0.09 & 0.04 & 0.06 & 0.09 \\
\hline 0.01 & 0.26 & 0.40 & 0.59 & 0.14 & 0.21 & 0.32 & 0.08 & 0.12 & 0.18 \\
\hline 0.02 & 0.31 & 0.47 & 0.71 & 0.18 & 0.26 & 0.40 & 0.11 & 0.17 & 0.25 \\
\hline 0.05 & 0.41 & 0.61 & 0.92 & 0.26 & 0.39 & 0.59 & 0.18 & 0.26 & 0.40 \\
\hline 0.10 & 0.52 & 0.79 & 1.18 & 0.37 & 0.56 & 0.84 & 0.27 & 0.40 & 0.60 \\
\hline 0.20 & 0.72 & 1.08 & 1.62 & 0.56 & 0.84 & 1.26 & 0.44 & 0.65 & 0.98 \\
\hline 0.30 & 0.92 & 1.38 & 2.08 & 0.77 & 1.16 & 1.74 & 0.63 & 0.95 & 1.43 \\
\hline 0.40 & 1.14 & 1.71 & 2.57 & 1.01 & 1.52 & 2.28 & 0.90 & 1.34 & 2.01 \\
\hline 0.50 & 1.41 & 2.12 & 3.18 & 1.30 & 1.95 & 2.93 & 1.22 & 1.83 & 2.74 \\
\hline 0.60 & 1.71 & 2.57 & 3.86 & 1.69 & 2.54 & 3.80 & 1.66 & 2.49 & 3.74 \\
\hline 0.70 & 2.17 & 3.26 & 4.89 & 2.22 & 3.34 & 5.00 & 2.30 & 3.45 & 5.18 \\
\hline 0.80 & 2.86 & 4.29 & 6.43 & 3.15 & 4.72 & 7.08 & 3.36 & 5.04 & 7.56 \\
\hline 0.90 & 4.20 & 6.30 & 9.44 & 5.00 & 7.49 & 11.24 & 5.89 & 8.84 & 13.26 \\
\hline 0.95 & 5.83 & 8.74 & 13.11 & 7.52 & 11.28 & 16.92 & 9.10 & 13.66 & 20.49 \\
\hline 0.98 & 8.33 & 12.49 & 18.73 & 11.65 & 17.47 & 26.21 & 15.43 & 23.15 & 34.72 \\
\hline 0.99 & 10.43 & 15.65 & 23.48 & 15.18 & 22.76 & 34.15 & 21.42 & 32.13 & 48.20 \\
\hline
\end{tabular}

